\title{
Tuberculosis and viral hepatitis infection in Eastern Europe, Asia, and Latin America: impact of tumor necrosis factor- $\alpha$ inhibitors in clinical practice
}

This article was published in the following Dove Press journal:

Biologics:Targets and Therapy

\section{Yi-Hsing Chen' \\ Hellen MDS de Carvalho ${ }^{2}$ \\ Umut Kalyoncu ${ }^{3}$ \\ Lyndon John Q Llamado4 \\ Gaston Solano 5 \\ Ron Pedersen 6 \\ Galina Lukina ${ }^{7}$ \\ Juan J Lichauco ${ }^{8}$ \\ Radu S Vasilescu ${ }^{9}$ \\ 'Division of Allergy, Immunology, and Rheumatology, Taichung Veterans \\ General Hospital, Taichung City, \\ Taiwan; ${ }^{2}$ Unidade de Reumatologia, \\ Hospital de Base do Distrito Federal, \\ Brasilia, Brazil; ${ }^{3}$ Department of \\ Internal Medicine, Faculty of Medicine, \\ Division of Rheumatology, Hacettepe \\ University, Ankara, Turkey; ${ }^{4}$ Pfizer, \\ Makati City, Philippines; ${ }^{5}$ Pfizer, San \\ Jose, Costa Rica; ${ }^{6}$ Pfizer, Collegeville, \\ PA, USA; ${ }^{7}$ Moscow Clinical Scientific \\ Center, Moscow, Russia; ${ }^{8}$ Section \\ of Rheumatology, Department of \\ Medicine, St. Luke's Medical Center, \\ Quezon City, Manila, Philippines; \\ ${ }^{9}$ Pfizer, Brussels, Belgium}

Correspondence: Lyndon John Q Llamado

Pfizer, 23F Ayala Life FGU Center, 68II Ayala Avenue, Makati City I200,

Philippines

Tel +63 9| 7820 II67

Email Lyndonjohn.Llamado@Pfizer.com

\begin{abstract}
Tumor necrosis factor- $\alpha$ (TNF- $\alpha)$ inhibitors are increasingly becoming the standard of care for treating a number of inflammatory diseases. However, treatment with TNF- $\alpha$ inhibitors carries an inherent risk of compromising the immune system, resulting in an increased susceptibility to infections and malignancies. This increased risk of infection is of particular concern in Asia, Eastern Europe, and Latin America where tuberculosis (TB) and viral hepatitis are endemic. In this brief review, we examine the literature and review the impact of TNF- $\alpha$ inhibitors on the incidence and the reactivation of latent disease with respect to TB, hepatitis $\mathrm{C}$ infection, and hepatitis B infection. Our findings show that TNF- $\alpha$ inhibitors are generally safe, if used with caution. Patients should be screened prior to the initiation of TNF- $\alpha$ inhibitor treatment and given prophylactic treatment if needed. In addition, patients should be monitored during treatment with TNF- $\alpha$ inhibitors and after treatment has stopped to ensure that infections, if detected, are treated promptly and effectively. Our analysis is consistent with other reports and guidelines.
\end{abstract}

Keywords: tuberculosis, hepatitis C, hepatitis B, tumor necrosis factor inhibitors, reactivation, risk

\section{Introduction}

Tumor necrosis factor- $\alpha$ (TNF- $\alpha$ ) inhibitors have been the standard of treatment for several inflammatory, autoimmune diseases including rheumatoid arthritis (RA), ankylosing spondylitis, psoriatic arthritis, juvenile idiopathic arthritis, and psoriasis. However, since TNF- $\alpha$ plays an essential role in the host immune system and its defense against infectious diseases, treatment with TNF- $\alpha$ inhibitors may adversely compromise the immune system in these patients and, consequently, increase the risk of developing infections and certain malignancies, particularly lymphoma and lung cancer. ${ }^{1-4}$ Although there are several TNF- $\alpha$ inhibitors currently in use to treat patients with RA, an extensive search in PubMed for publications addressing the use of these agents in patients with risk of tuberculosis (TB) or hepatitis yielded only articles in which etanercept (a human soluble dimeric TNF- $\alpha$ receptor fusion protein), ${ }^{5}$ adalimumab (a fully human monoclonal antibody $[\mathrm{mAb}]$ against TNF- $\alpha$ ), ${ }^{5}$ or infliximab (a mouse-human chimeric $\mathrm{mAb}$ against TNF- $\alpha)^{5}$ was used. Consequently, in this article, we review the impact of treating with only these three TNF- $\alpha$ inhibitors on the incidence of TB and reactivation rate of viral hepatitis and the clinical outcomes in patients. 


\section{TB}

The global burden of TB continues to be very high. ${ }^{6,7}$ It is estimated that globally, 9 million people developed TB, 1.5 million died from the disease in 2013, and that onethird of the world's population has latent TB. ${ }^{6,8}$ Incidence of TB is high in Asia, Eastern Europe, Latin America, and sub-Saharan Africa, with $56 \%$ of cases occurring in Southeast Asia and Western Pacific. ${ }^{6,7}$ Eastern European and Central Asian countries continue to have the highest incidence of multidrug-resistant TB. ${ }^{6}$ In India alone, there are 2.2 million new cases of TB and more than 300,000 deaths each year. ${ }^{9}$

Increased incidence of TB in patients treated with TNF- $\alpha$ inhibitors was first reported for infliximab. ${ }^{10}$ Since then, several studies have indicated that the risk for TB is higher in patients treated with TNF- $\alpha$ inhibitors. ${ }^{11-21}$ A biphasic emergence of TB infection among patients with RA using TNF- $\alpha$ inhibitors has been reported due to the reactivation of latent TB infection (LTBI) or new TB infection. ${ }^{22}$ The reported standardized incidence ratio for etanercept was in the range of 0.4-2.2 compared to 1.7-18.6 for infliximab and 0.9-29.3 for adalimumab. ${ }^{14-17}$ The reported incidence rate per 100,000 patient years was 540 for patients with ankylosing spondylitis treated with infliximab compared to 490 for patients treated with adalimumab; no cases of TB were reported for patients treated with etanercept. ${ }^{18}$ These data indicate that in general, the risk of TB infection appears to be higher for patients treated with anti-TNF- $\alpha$ mAbs (infliximab/adalimumab) than for patients treated with TNF- $\alpha$ soluble receptor (etanercept), and among the mAbs, it appears to be higher for patients treated with infliximab than for patients treated with adalimumab (Table 1). ${ }^{14-21}$ Structural and functional disparities between the mAbs and soluble receptor may be the reason for this difference in response..$^{23}$

The consequences of new infection or reactivation of LTBI in patients prescribed treatment with TNF- $\alpha$ inhibitors could be extremely harmful or even fatal. ${ }^{24}$ Thus, it is imperative that patients in $\mathrm{TB}$ endemic areas eligible for TNF- $\alpha$ inhibitor therapy are tested for TB/LTBI so that, if needed, appropriate chemoprophylaxis can be administered prior to the initiation of treatment. Patients detected with LTBI when given prophylactic treatment with isoniazid or rifampin/isoniazid prior to TNF- $\alpha$ inhibitor therapy had a low rate of conversion to disease. ${ }^{25-29}$

Given the potential damaging effect of TB on the patient, the threshold for initiating chemoprophylaxis is understandably low. ${ }^{30,31}$ However, initiating chemoprophylaxis delays critical TB treatment, potentially exacerbating the disease and adding to costs that may not be affordable in many regions. Chemoprophylaxis also can cause its own adverse events, further negatively affecting the patient's quality of life. ${ }^{32}$ Testing can be done using either the tuberculin skin test (TST) or the interferon gamma release assay (IGRA). TST is sensitive, specific to TB, and identifies all patients who have been exposed to TB. However, it does not differentiate between individuals with active TB, latent TB, or those immunized against TB with a Bacillus Calmette-Guérin (BCG) vaccine. ${ }^{33}$ IGRA has increased the detection of LTBI, especially in patients with immunological diseases, ${ }^{22,34,35}$ in countries where the population is universally vaccinated with BCG. However, the sensitivity and specificity of IGRA has not yet been fully verified and its use is not universal. ${ }^{29,33,36}$ Recent studies have shown that using a multistep approach that includes TST, chest X-ray, and IGRA to screen patients who are candidates for TNF- $\alpha$ inhibitor therapy identifies those patients for whom chemoprophylaxis is essential. ${ }^{29,37,38}$ These approaches decreased the number of patients who underwent chemoprophylaxis, thereby enabling more patients to receive the anti-TB treatment earlier. The subsequent incidence of TB was comparable to that in countries where TB is not endemic. ${ }^{29,39,40}$ It is recommended that patients receiving TNF- $\alpha$ inhibitor therapy be screened at least annually for new TB infection or the emergence of LTBI. ${ }^{41}$ Serial IGRA monitoring has been shown to be effective in detecting active TB in patients with RA receiving TNF- $\alpha$ inhibitor therapy. ${ }^{22}$ Prophylactic monitoring of patients and selecting appropriate treatment have subsequently reduced the overall costs of treatment.

Given the potential for very severe consequences due to TB infection or LTBI reactivation in patients receiving TNF- $\alpha$ inhibitor therapy, it is imperative that they be monitored regularly during their treatment to ensure timely treatment for latent or active TB. Care must be taken in the interpretation of TB test results in patients receiving chemoprophylaxis or TNF- $\alpha$ inhibitors, since treatment and the tests themselves can affect subsequent test results. ${ }^{42,43}$ This review confirms earlier findings indicating that TNF- $\alpha$ inhibitors are safe to use with appropriate monitoring even in patients who are immunocompromised and at high risk for TB.

\section{Viral hepatitis C}

The global burden of hepatitis $\mathrm{C}$ is high, and the prevalence of hepatitis $\mathrm{C}$ virus (HCV) infection worldwide is estimated to be $2.8 \%$ of the population, ie, $>185$ million people, with 3-4 million people being newly infected each year. ${ }^{44}$ Prevalence is high (>3.5\%) in countries of Central and East Asia, North Africa, 
Table I Risk of tuberculosis associated with TNF- $\alpha$ inhibitor treatment

\begin{tabular}{|c|c|c|c|}
\hline Drug & Study details & Outcomes & Reference \\
\hline Infliximab & $\begin{array}{l}\text { Analysis of reports of TB in the FAERS } \\
\text { MedWatch program from I998 to May 29, 200I } \\
\text { (http://www.fda.gov/cder/aers/) }\end{array}$ & $\begin{array}{l}70 \text { reported cases of TB after treatment with infliximab } \\
\text { for a median of I } 2 \text { weeks; in } 48 \text { patients, TB developed } \\
\text { after } \leq 3 \text { infusions; } 40 \text { patients had extrapulmonary } \\
\text { disease }\end{array}$ & 10 \\
\hline $\begin{array}{l}\text { Infliximab, } \\
\text { adalimumab, both }\end{array}$ & $\begin{array}{l}873 \text { IBD subjects treated with TNF- } \alpha \text { inhibitors } \\
\text { from January } 2001 \text { to December } 2013\end{array}$ & $\begin{array}{l}25 \text { newly developed TB cases; adjusted SIR, } 41.7 \text { ( } 95 \% \\
\text { CI: } 25.3-58.0 \%) ; 19 \text { patients developed TB within } \\
\text { 2-62 months of treatment initiation; treatment with } \\
\text { infliximab was a significant predictor of TB }(P=0.033)\end{array}$ & 12 \\
\hline $\begin{array}{l}\text { Infliximab, } \\
\text { adalimumab }\end{array}$ & $\begin{array}{l}\text { Retrospective analysis of serious infections within } \\
6 \text { months of initiation of TNF- } \alpha \text { inhibitor therapy }\end{array}$ & $\begin{array}{l}\text { TB occurred in } 3 / 175 \text { patients; none treated with anti- } \\
\text { TB chemoprophylaxis prior to treatment with TNF- } \alpha \\
\text { inhibitor }\end{array}$ & 13 \\
\hline $\begin{array}{l}\text { Infliximab, } \\
\text { adalimumab, } \\
\text { etanercept }\end{array}$ & $\begin{array}{l}\text { Incidence study and case-control analysis to } \\
\text { determine risk of TB in patients treated with } \\
\text { TNF- } \alpha \text { inhibitor in the French RATIO registry } \\
\text { over } 3 \text { years }\end{array}$ & $\begin{array}{l}\text { No patient received anti-TB chemoprophylaxis; overall } \\
\text { adjusted SIR }(95 \% \mathrm{CI}), \text { I } 2.2(9.7-15.5 \%) \text {; for infliximab, } \\
\text { I8.6 (I3.4-25.8\%); adalimumab, } 29.3(20.3-42.4 \%) \text {; } \\
\text { etanercept, I.8 (0.7-4.3\%); treatment with infliximab or } \\
\text { adalimumab versus etanercept was an independent risk } \\
\text { factor for TB with OR }(95 \% \mathrm{Cl}) \text { I3.3 }(2.6-69.0 \%) \text { and } \\
\text { I7.I (3.6-80.6\%), respectively }\end{array}$ & 14 \\
\hline $\begin{array}{l}\text { Infliximab, } \\
\text { adalimumab, } \\
\text { etanercept }\end{array}$ & $\begin{array}{l}\text { Review of medical records from } 2002 \text { to } 2009 \\
\text { among patients with AS treated with other agents } \\
(n=9 \text { |9) or TNF- } \alpha \text { inhibitors }(n=354) \text { for new } \\
\text { cases of TB; reference data from the Korean } \\
\text { National Tuberculosis Association }\end{array}$ & $\begin{array}{l}\text { Mean TB incidence rate per } 100,000 \text { PY }=69.8 \text { in } \\
\text { general population versus } 308 \text { in AS patients treated } \\
\text { with other agents versus } 561 \text { in AS patients treated } \\
\text { with TNF- } \alpha \text { inhibitors. Incidence rates for infliximab, } \\
540 \text {; adalimumab, } 490 \text {; etanercept, } 0\end{array}$ & 18 \\
\hline TNF- $\alpha$ inhibitors & $\begin{array}{l}\text { Retrospective analysis of } 949 \text { patients treated } \\
\text { with TNF- } \alpha \text { inhibitors at the Yonsei University } \\
\text { Health System from } 2005 \text { to } 2012 \text { evaluating } \\
\text { incidence of active TB between LTBI-positive } \\
(n=256) \text { and -negative patients }(n=52 I)\end{array}$ & $\begin{array}{l}\text { Active TB incidence rate per } 100,000 \mathrm{PY}=1,107 \text { in } \\
\text { LTBI-positive patients; } 490 \text { in LTBI-negative patients }\end{array}$ & 19 \\
\hline TNF- $\alpha$ inhibitors & $\begin{array}{l}\text { Literature review of articles published in PubMed } \\
\text { from January } 2000 \text { to October } 20 \mathrm{II} \text { and data } \\
\text { from China Hospital Knowledge Database; RA } \\
\text { and AS patients from Africa, Middle East, and Asia }\end{array}$ & $\begin{array}{l}\text { Risk for active TB and other infections increased in } \\
\text { patients receiving TNF- } \alpha \text { inhibitors; risk is higher } \\
\text { among those treated with monoclonal antibodies versus } \\
\text { soluble TNF- } \alpha \text { receptor }\end{array}$ & 15 \\
\hline $\begin{array}{l}\text { Infliximab, } \\
\text { adalimumab, } \\
\text { etanercept }\end{array}$ & $\begin{array}{l}\text { ARI of TB was estimated using published SIR from } \\
\text { the French RATIO registry and incidence of TB. } \\
\text { The NNH for each TNF- } \alpha \text { inhibitor and the NNT } \\
\text { to reduce I TB event using etanercept instead of } \\
\text { adalimumab or infliximab were calculated }\end{array}$ & $\begin{array}{l}\text { The ARI of TB with anti-TNF- } \alpha \text { therapies in Asian } \\
\text { countries is substantially higher than Western Europe } \\
\text { and North America. NNH ranges were } 8-163 \text { for } \\
\text { adalimumab, I26-2,646 for etanercept, and I2-256 } \\
\text { for infliximab. The NNT to reduce I TB event using } \\
\text { etanercept instead of adalimumab ranged from } 8 \text { to } 173 \\
\text { and using etanercept instead of infliximab from I3 to } \\
283\end{array}$ & 20 \\
\hline $\begin{array}{l}\text { Adalimumab, } \\
\text { etanercept }\end{array}$ & $\begin{array}{l}\text { Retrospective cohort study on RA patients } \\
\text { treated with TNF- } \alpha \text { inhibitors from } 2006 \text { to } \\
2008 \text { using data from Taiwan's National Health } \\
\text { Insurance claims databases. Primary outcome: } \\
\text { active TB; TB risk estimated using Cox's } \\
\text { proportional hazard model }\end{array}$ & $\begin{array}{l}\text { Active TB rates per } 100,000 \text { PY were } 1,4 \mathrm{II} .3 \text { for } \\
\text { patients treated with adalimumab and } 679.5 \text { for patients } \\
\text { treated with etanercept. Patients treated with TNF- } \alpha \\
\text { inhibitors had a higher risk of TB (aHR } 4.87 \text { [ } 95 \% \mathrm{Cl} \text { : } \\
2.14-11.06 \%] \text { ) }\end{array}$ & 16 \\
\hline
\end{tabular}

Abbreviations: aHR, adjusted hazard ratio; ARI, absolute risk increase; AS, ankylosing spondylitis; Cl, confidence interval; IBD, inflammatory bowel disease; LTBI, latent TB infection; NNH, number needed to harm; NNT, number needed to treat; OR, odds ratio; PY, patient year(s); RA, rheumatoid arthritis; SIR, standardized incidence ratio; TB, tuberculosis; TNF- $\alpha$, tumor necrosis factor- $\alpha$.

and the Middle East and moderate (1.5-3.5\%) in countries of South and Southeast Asia, sub-Saharan Africa, Latin America, and Europe. ${ }^{44}$ It is estimated that 7-9 million people in Latin America are seropositive for HCV, with Grenada, Bolivia, Haiti, Trinidad and Tobago, and El Salvador having the highest prevalence $(>2.5 \%) .{ }^{45,46}$ Each year, there are $>54,000$ deaths directly attributable to $\mathrm{HCV}$ infection. ${ }^{44}$ As such, it is important to ensure that drugs being administered for concurrent diseases do not activate latent $\mathrm{HCV}$ infection and/or make the patient more susceptible to new HCV infection. 
For the most part, infection with $\mathrm{HCV}$ has been reported to increase the secretion of TNF- $\alpha \cdot{ }^{47-51}$ However, it has also been reported that induced release of TNF- $\alpha$ from monocytes of patients chronically infected with $\mathrm{HCV}$ was decreased. ${ }^{52}$ Although there are no large-scale studies to date evaluating the impact of treatment with TNF- $\alpha$ inhibitors on $\mathrm{HCV}$ reactivation, several small studies suggest that the risk is low (Table 2). ${ }^{53-58}$ In general, the consensus appears to be that as long as prophylactic therapy is used, treatment with TNF- $\alpha$ inhibitors does not significantly increase the risk of HCV reactivation or reinfection. ${ }^{59-64}$ It has been reported that $\mathrm{HCV}$ viral load did not change significantly after 2 years of treatment with TNF- $\alpha$ inhibitors even when specific antiHCV treatment was not administered.$^{65}$ Based on low level of evidence, the 2015 American College of Rheumatology guidelines to treat patients with RA recommend the use of biological agents concurrent with antiviral therapy in patients simultaneously infected with $\mathrm{HCV}$ and the potential use of etanercept to treat RA patients with chronic $\mathrm{HCV}$ infection. ${ }^{66}$

\section{Viral hepatitis B}

It is estimated that globally, 240-350 million people are chronically infected with hepatitis B virus (HBV); the prevalence is highest in sub-Saharan Africa and East Asia, where $5-15 \%$ of the adult population are chronically infected. ${ }^{67,68}$ In the Middle East and the Indian subcontinent, it is estimated that $2-5 \%$ of the general population are chronically infected. Other regions with high rates of chronic infection include the
Amazon basin, Central and Eastern Europe, and Alaska. ${ }^{67}$ By comparison, $<1 \%$ of the population in Western Europe and North America are chronically infected with HBV. More than 600,000 people die each year due to complications from HBV infection, including acute hepatitis, liver cirrhosis, and hepatocellular carcinoma. ${ }^{67,69}$ In animal models of HBV infection, TNF- $\alpha$ produced by HBV-specific cytotoxic T cells inhibits HBV regulation. ${ }^{70}$ It is conceivable, therefore, that inhibiting the TNF- $\alpha$ production may result in adventitious reactivation of HBV. Thus, it is critical that TNF- $\alpha$ inhibitors administered to treat concurrent diseases be evaluated for their potential to cause reactivation of $\mathrm{HBV}$ infection and/ or make the patient more susceptible to new HBV infection.

Treatment with immunosuppressive agents has been reported to increase the incidence of reactivation of chronic HBV in up to $25 \%$ of patients (Table 3 ) ${ }^{64,71-73} \mathrm{HBV}$ reactivation in patients with chronic inactive/resolved HBV infection undergoing immunosuppressive treatment is defined as an increase of $\geq 1 \log _{10} \mathrm{IU} / \mathrm{mL}$ plus increase in serum HBV-DNA level or the detection of previously undetectable HBV-DNA, and serum alanine aminotransferase (ALT) elevation $>2-3 \times$ upper limit of normal. An increase in liver function tests (hepatitis) usually follows viral reactivation. ${ }^{74,75}$ To date, there are no large-scale prospective studies evaluating the risk of $\mathrm{HBV}$ reactivation in response to treatment with TNF- $\alpha$ inhibitors. A number of studies reported HBV reactivation, ${ }^{76-83}$ whereas some studies reported otherwise. ${ }^{53,58,71,84}$ Even in studies where reactivation was reported, prophylactic

Table 2 Risk of hepatitis C reinfection associated with TNF- $\alpha$ inhibitor treatment

\begin{tabular}{|c|c|c|c|}
\hline Drug & Study details & Outcomes & Reference \\
\hline $\begin{array}{l}\text { Adalimumab, } \\
\text { etanercept }\end{array}$ & $\begin{array}{l}\text { Retrospective analysis determining the rate of } \mathrm{HCV} \\
\text { or } \mathrm{HBV} \text { reinfection in RA patients with prior } \mathrm{HCV} \\
\text { or } \mathrm{HBV} \text { infection }\end{array}$ & $\begin{array}{l}\text { No cases of HCV or HBV reactivation in any patients. } \\
\text { Increased transaminases observed in slightly over } 20 \% \\
\text { of patients, which was associated with concomitant } \\
\text { DMARD use, isoniazid prophylaxis, or alcohol abuse }\end{array}$ & 53 \\
\hline TNF- $\alpha$ inhibitors & $\begin{array}{l}\text { Retrospective analysis of viral load and liver enzymes } \\
\text { in PsA patients with concurrent } \mathrm{HCV} \text { infection }\end{array}$ & $\begin{array}{l}\text { In most patients, viral load and liver enzymes remained } \\
\text { stable through } 12 \text { months of observation }\end{array}$ & 54 \\
\hline $\begin{array}{l}\text { Adalimumab, } \\
\text { etanercept, } \\
\text { infliximab }\end{array}$ & $\begin{array}{l}\text { Evaluation of RA patients with concurrent HCV } \\
\text { infection treated with TNF- } \alpha \text { inhibitors at standard } \\
\text { doses }\end{array}$ & $\begin{array}{l}\text { Patients exhibited improvements in all RA-related } \\
\text { disease characteristics and general health with benefits } \\
\text { persisting up to } 22 \text { months of follow-up. There were no } \\
\text { significant changes in viral load or liver enzymes }\end{array}$ & 55 \\
\hline Etanercept & $\begin{array}{l}\text { Prospective, open-label evaluation of RA patients } \\
\text { with concurrent HCV infection treated with } \\
\text { etanercept, methotrexate, or combination of the } \\
\text { two drugs }\end{array}$ & $\begin{array}{l}\text { Patients exhibited improvements in all RA-related } \\
\text { disease characteristics. There were no significant } \\
\text { changes in viral load or liver enzymes in any of the three } \\
\text { treatment arms }\end{array}$ & 56 \\
\hline $\begin{array}{l}\text { Etanercept, } \\
\text { infliximab }\end{array}$ & $\begin{array}{l}\text { Retrospective survey of RA patients with concurrent } \\
\mathrm{HCV} \text { infection treated with etanercept or infliximab }\end{array}$ & $\begin{array}{l}\text { There were no significant changes in viral load or liver } \\
\text { enzymes in response to treatment with TNF- } \alpha \text { inhibitors }\end{array}$ & 57 \\
\hline $\begin{array}{l}\text { Adalimumab, } \\
\text { etanercept }\end{array}$ & $\begin{array}{l}\text { Retrospective analysis of plaque psoriasis patients } \\
\text { with concurrent } \mathrm{HCV} \text { and/or } \mathrm{HBV} \text { infection }\end{array}$ & $\begin{array}{l}\text { There were no significant changes in viral load or liver } \\
\text { enzymes in response to treatment with TNF- } \alpha \text { inhibitors }\end{array}$ & 58 \\
\hline
\end{tabular}

Abbreviations: DMARD, disease-modifying antirheumatic drug; $\mathrm{HBV}$, hepatitis $B$ virus; $\mathrm{HCV}$, hepatitis $\mathrm{C}$ virus; PsA, psoriatic arthritis; RA, rheumatoid arthritis; TNF- $\alpha$, tumor necrosis factor- $\alpha$. 
Table 3 Risk of hepatitis B reinfection associated with TNF- $\alpha$ inhibitor treatment

\begin{tabular}{|c|c|c|c|}
\hline Drug & Study details & Outcomes & Reference \\
\hline $\begin{array}{l}\text { Adalimumab, } \\
\text { etanercept }\end{array}$ & $\begin{array}{l}\text { Retrospective analysis determining the rate of } \mathrm{HCV} \\
\text { or } \mathrm{HBV} \text { reinfection in RA patients with prior } \mathrm{HCV} \\
\text { or } \mathrm{HBV} \text { infection }\end{array}$ & $\begin{array}{l}\text { No cases of } \mathrm{HCV} \text { or } \mathrm{HBV} \text { reactivation in any patients. } \\
\text { Increased transaminases observed in slightly over } 20 \% \\
\text { of patients, which was associated with concomitant } \\
\text { DMARD use, isoniazid prophylaxis, or alcohol abuse }\end{array}$ & 53 \\
\hline $\begin{array}{l}\text { Adalimumab, } \\
\text { etanercept, } \\
\text { infliximab }\end{array}$ & $\begin{array}{l}\text { Determination of rate of HBV reactivation in } \\
\text { patients, with RA or spondyloarthropathy previously } \\
\text { infected with HBV, treated with one or more TNF- } \alpha \\
\text { inhibitors }\end{array}$ & No cases of reactivation observed & 71 \\
\hline TNF- $\alpha$ inhibitors & $\begin{array}{l}\text { Retrospective evaluation of } \mathrm{HBV} \text { reactivation in } \\
\text { patients with rheumatic diseases treated with TNF- } \alpha \\
\text { inhibitors }\end{array}$ & $\begin{array}{l}\text { Reactivation occurred in } 1 / 8 \text { patients who were } \\
\text { inactive HBV surface antigen carriers }\end{array}$ & 76 \\
\hline TNF- $\alpha$ inhibitors & $\begin{array}{l}\text { Retrospective review to determine HBV reactivation } \\
\text { in RA patients treated with TNF- } \alpha \text { inhibitors }\end{array}$ & $\begin{array}{l}\text { There were no cases of HBV reactivation in patients } \\
\text { receiving prophylactic antiviral therapy. In patients } \\
\text { not receiving antiviral therapy, HBV reactivation } \\
\text { occurred in } 5 / 8(62.5 \%) \text { patients }\end{array}$ & 77 \\
\hline $\begin{array}{l}\text { Adalimumab, } \\
\text { etanercept, } \\
\text { infliximab }\end{array}$ & $\begin{array}{l}\text { Meta-analysis to measure HBV reactivation in TNF- } \alpha \\
\text { inhibitor-treated patients with rheumatic diseases } \\
\text { who were occult carriers of HBV }\end{array}$ & $\begin{array}{l}\text { HBV reactivation was observed in } 8 / 468(1.7 \%) \\
\text { patients }\end{array}$ & 78 \\
\hline $\begin{array}{l}\text { Adalimumab, } \\
\text { etanercept, } \\
\text { infliximab }\end{array}$ & $\begin{array}{l}\text { Systematic review to evaluate HBV reactivation in } \\
\text { TNF- } \alpha \text { inhibitor-treated patients with rheumatic } \\
\text { diseases who were occult carriers of HBV }\end{array}$ & $\begin{array}{l}\text { HBV reactivation was observed in } 15 / 122(39.3 \%) \\
\text { patients }\end{array}$ & 79 \\
\hline TNF- $\alpha$ inhibitors & $\begin{array}{l}\text { Systematic analysis to evaluate HBV reactivation in } \\
\text { patients who were occult carriers of HBV treated } \\
\text { with TNF- } \alpha \text { inhibitors }\end{array}$ & $\begin{array}{l}\text { HBV reactivation was reported in } 35 / 89(39 \%) \\
\text { patients positive for HBV surface antigen. HBV } \\
\text { reactivation was higher in patients previously treated } \\
\text { with immunosuppressive agents and lower in those } \\
\text { who received antiviral prophylaxis }\end{array}$ & 80 \\
\hline $\begin{array}{l}\text { Adalimumab, } \\
\text { etanercept }\end{array}$ & $\begin{array}{l}\text { Retrospective analysis of plaque psoriasis patients } \\
\text { with concurrent } \mathrm{HCV} \text { and/or } \mathrm{HBV} \text { infection }\end{array}$ & $\begin{array}{l}\text { There were no significant changes in viral load or } \\
\text { liver enzymes in response to treatment with TNF- } \alpha \\
\text { inhibitors }\end{array}$ & 58 \\
\hline TNF- $\alpha$ inhibitors & $\begin{array}{l}\text { Prospective study determining HBV reactivation in } \\
\text { patients with chronic HBV infection, resolved HBV } \\
\text { infection, or vaccinated against HBV }\end{array}$ & $\begin{array}{l}\text { HBV reactivation observed in only one patient due to } \\
\text { the emergence of lamivudine-resistant mutant strain } \\
\text { of virus. No other incidence of HBV reactivation } \\
\text { observed }\end{array}$ & 81 \\
\hline TNF- $\alpha$ inhibitors & $\begin{array}{l}\text { Assessment of HBV reactivation in patients with } \\
\text { inflammatory arthritis treated with TNF- } \alpha \text { inhibitors }\end{array}$ & $\begin{array}{l}\text { HBV reactivation observed in } 2 / 6 \text { patients with } \\
\text { chronic HBV infection who received no antiviral } \\
\text { prophylaxis, but not in the other four patients who } \\
\text { did. In } 3 \text { I inactive carriers, increase in viral load was } \\
\text { observed in } 6 / 22(27.3 \%) \text { patients without antiviral } \\
\text { prophylaxis, but no increase in the nine patients who } \\
\text { received it. No HBV reactivation observed in } 50 \\
\text { patients with resolved HBV infection }\end{array}$ & 82 \\
\hline TNF- $\alpha$ inhibitors & $\begin{array}{l}\text { Retrospective analysis of } \mathrm{HBsAg-positive} \mathrm{patients} \\
\text { who received DMARDs }\end{array}$ & $\begin{array}{l}\text { HBV reactivation was demonstrated in } \sim 17 \% \text { of } \\
\text { patients receiving immunosuppressive treatment, } 12 \% \\
\text { of patients receiving antiviral prophylaxis, and } 24 \% \text { of } \\
\text { patients not receiving antiviral prophylaxis }\end{array}$ & 83 \\
\hline Infliximab & $\begin{array}{l}\text { Retrospective analysis of RA patients treated with } \\
\text { infliximab with prior exposure to HBV }\end{array}$ & $\begin{array}{l}\text { There was no statistically significant difference in } \\
\text { liver enzymes between infliximab-treated patients } \\
\text { with prior exposure to HBV and those without such } \\
\text { exposure }\end{array}$ & 84 \\
\hline
\end{tabular}

Abbreviations: DMARD, disease-modifying antirheumatic drug; $\mathrm{HBV}$, hepatitis $B$ virus; $\mathrm{HBs} A$ g, hepatitis $B$ surface antigen; $\mathrm{HCV}$, hepatitis $\mathrm{C}$ virus; $\mathrm{RA}$, rheumatoid arthritis; TNF- $\alpha$, tumor necrosis factor- $\alpha$.

treatment with an antiviral agent appeared to prevent reactivation. ${ }^{77,80-82}$ Expert opinion indicates that treatment with TNF- $\alpha$ inhibitors is generally safe, with an overall low risk of HBV reactivation in areas of low HBV prevalence. ${ }^{59,64,72,85-87}$
It is strongly recommended that patients with active or chronic HBV infection be given preemptive antiviral treatment 1-2 weeks prior to, during, and for at least 6 months after stoppage of TNF- $\alpha$ inhibitor treatment to reduce the 
risk of HBV reactivation. ${ }^{59,64,72,86-89}$ Furthermore, these same guidelines recommend that patients who have occult $\mathrm{HBV}$ infection (HB surface antigen negative, anti-HBc antibody positive, and HBV-DNA positive) or with a history of $\mathrm{HBV}$ infection but seronegative at the time of initiation of TNF- $\alpha$ inhibitor therapy should be closely monitored for potential reactivation so that antiviral prophylaxis can be administered in a timely manner.

\section{Discussion}

One of the limitations of this review is that data on the effects of treating patients with RA who were at risk for TB or hepatitis infection were available for only three TNF- $\alpha$ inhibitors: etanercept, adalimumab, and infliximab. Consequently, although it would be difficult to draw a general conclusion for the whole class of TNF- $\alpha$ inhibitors, it is expected that other TNF- $\alpha$ inhibitors would behave similarly.

Based on the available information ${ }^{56,90-95}$ and our own clinical practices, our recommendations for how to treat patients with RA who are at risk for infection with TB, hepatitis $C$, or hepatitis B are summarized in Table 4. For patients with a risk of infection with TB or reactivation of LTBI, we recommend 1) an initial screen with at least TST, preferably followed with an IGRA for those who were immunized with $\mathrm{BCG}$; 2) a minimum prophylactic treatment of 1 month prior to the initiation of treatment with TNF- $\alpha$ inhibitors, regardless of the prophylactic treatment used since they vary by country; and 3) monitoring regularly, at least once a month. For patients with a high risk of HCV infection, we recommend consultation with a hepatologist to determine whether or not antiviral prophylactic treatment is needed, eg, with cyclosporine A, ribavirin, and/or interferon. For other patients, we recommend treating with a TNF- $\alpha$ inhibitor, preferably one that has the least risk of HCV infection or reactivation, eg, etanercept along with regular monitoring, at least once a month, to determine whether antiviral treatment needs to be initiated. For patients with active or a high risk of HBV infection, we recommend prophylactic antiviral treatment for at least 2 weeks prior to the initiation of treatment with a TNF- $\alpha$ inhibitor and for 6 months following cessation of this treatment. The choice of antiviral treatment should be made in consultation with a hepatologist. For patients with suspected HBV infection, we recommend testing for HBV surface antigen prior to initiating prophylactic antiviral or TNF- $\alpha$ inhibitor treatment. Patients should be monitored throughout the period during which they are receiving TNF- $\alpha$ inhibitor treatment, at least once a month.

\section{Conclusion}

This review confirms earlier findings that TNF- $\alpha$ inhibitors are safe to use with appropriate monitoring and chemoprophylaxis at high risk for TB infection and TB or viral hepatitis reactivation.

Table 4 Treatment recommendations

\begin{tabular}{|c|c|c|}
\hline Infection & Recommendation & Notes \\
\hline \multirow[t]{4}{*}{ TB/LTBI } & $\begin{array}{l}\text { I. Screen for latent infection or exposure, eg, via } \\
\text { immunization }\end{array}$ & $\begin{array}{l}\text { I. Screening with at least TST, preferably followed with IGRA for } \\
\text { patients previously exposed or immunized with BCG }\end{array}$ \\
\hline & 2. Prophylactic treatment for at least I month & 2. Prophylactic treatment and length will depend on the country \\
\hline & 3. Choice of TNF- $\alpha$ inhibitor with least risk & 3. Etanercept (most data available) or secukinumab \\
\hline & $\begin{array}{l}\text { 4. Regular monitoring of patients for infection or } \\
\text { reactivation of LTBI }\end{array}$ & $\begin{array}{l}\text { 4. Suspend TNF- } \alpha \text { inhibitor treatment if infection discovered; restart } \\
\text { TNF- } \alpha \text { inhibitor treatment only if infection resolved }\end{array}$ \\
\hline \multirow[t]{4}{*}{$\mathrm{HCV}$} & $\begin{array}{l}\text { I. Consult with hepatologist if antiviral prophylaxis is needed } \\
\text { 2. Choice of TNF- } \alpha \text { inhibitor with least risk }\end{array}$ & $\begin{array}{l}\text { I. If prophylactic treatment is not used, patient must be monitored } \\
\text { more closely }\end{array}$ \\
\hline & 3. Regular monitoring of patients for infection or & 2. Etanercept (most data available) \\
\hline & reactivation of $\mathrm{HCV}$ & 3. Suspend TNF- $\alpha$ inhibitor treatment if infection discovered; restart \\
\hline & & TNF- $\alpha$ inhibitor treatment only if infection resolved \\
\hline \multirow[t]{6}{*}{ HBV } & $\begin{array}{l}\text { I. Test for } \mathrm{HBsAg} \text { to determine whether prophylactic } \\
\text { antiviral treatment is needed }\end{array}$ & $\begin{array}{l}\text { I. If prophylactic treatment is not used, patient must be monitored } \\
\text { more closely }\end{array}$ \\
\hline & $\begin{array}{l}\text { 2. Consult with hepatologist on antiviral prophylactic } \\
\text { treatment to be used }\end{array}$ & $\begin{array}{l}\text { 2. Choice of treatment with a single agent or a combination of agents } \\
\text { to ensure prevention of infection/reactivation }\end{array}$ \\
\hline & $\begin{array}{l}\text { 3. Prophylactic treatment for at least } 2 \text { weeks prior to } \\
\text { initiation of TNF- } \alpha \text { inhibitor }\end{array}$ & $\begin{array}{l}\text { 3. Antiviral prophylactic treatment should be initiated no later than } \\
\text { initiation of TNF- } \alpha \text { inhibitor treatment }\end{array}$ \\
\hline & 4. Choice of TNF- $\alpha$ inhibitor with least risk & 4. Etanercept (most data available) \\
\hline & $\begin{array}{l}\text { 5. Regular monitoring of all patients at risk for infection or } \\
\text { reactivation of } \mathrm{HCV}\end{array}$ & $\begin{array}{l}\text { 5. Suspend TNF- } \alpha \text { inhibitor treatment if infection discovered; restart } \\
\text { TNF- } \alpha \text { inhibitor treatment only if infection resolved }\end{array}$ \\
\hline & $\begin{array}{l}\text { 6. Antiviral treatment for at least } 6 \text { months after treatment } \\
\text { with TNF- } \alpha \text { inhibitor stopped }\end{array}$ & $\begin{array}{l}\text { 6. Consult with hepatologist if longer antiviral treatment is needed } \\
\text { after TNF- } \alpha \text { inhibitor stopped }\end{array}$ \\
\hline
\end{tabular}

Abbreviations: BCG, Bacillus Calmette-Guérin; HBV, hepatitis B virus; HBsAg, hepatitis B surface antigen; HCV, hepatitis C virus; IGRA, interferon gamma release assay; LTBI, latent tuberculosis infection; TB, tuberculosis; TNF- $\alpha$, tumor necrosis factor- $\alpha$; TST, tuberculin skin test. 


\section{Acknowledgments}

The authors thank Drs Paulo Louzada-Junior (Universidade de São Paulo, São Paulo, Brazil) and Ena Singh (Pfizer) for their input in the development of the article. Medical writing support was provided by Mukund Nori, PhD, MBA, CMPP, of Engage Scientific Solutions and was funded by Pfizer, New York, NY, USA.

\section{Author contributions}

All authors contributed to identifying articles for this review, data analysis, drafting, and critically revising the paper, and agree to be accountable for all aspects of the work.

\section{Disclosure}

Y-HC is on the advisory boards of AbbVie, Astellas, AstraZeneca, Bristol Myers Squibb, GlaxoSmithKline, Guigai, Inova Diagnostics, Johnson \& Johnson, Lilly, MSD, Novartis, Pfizer, Roche, and ThermoFisher Scientific and has received funding for research and clinical trials from AbbVie, Boehringer Ingelheim, Bristol Myers Squibb, Guigai, Johnson \& Johnson, MSD, Novartis, Pfizer, Roche, Sanofi, and UCB. HMDSdC is a consultant for AbbVie, AstraZeneca, Janssen, Novartis, Pfizer, and Roche. UK is a consultant for AbbVie, BMS, MSD, Pfizer, and UCB. LJQL, GS, RP, and RV are employees of Pfizer and own stock in the company. JJL is on the advisory board of Pfizer. The authors report no other conflicts of interest in this work.

\section{References}

1. Bongartz T, Sutton AJ, Sweeting MJ, Buchan I, Matteson EL, Montori V. Anti-TNF antibody therapy in rheumatoid arthritis and the risk of serious infections and malignancies: systematic review and metaanalysis of rare harmful effects in randomized controlled trials. JAMA. 2006;295(19):2275-2285.

2. Dixon WG, Watson K, Lunt M, Hyrich KL, Silman AJ, Symmons DP. Rates of serious infection, including site-specific and bacterial intracellular infection, in rheumatoid arthritis patients receiving anti-tumor necrosis factor therapy: results from the British Society for Rheumatology Biologics Register. Arthritis Rheum. 2006;54(8):2368-2376.

3. Ellerin T, Rubin RH, Weinblatt ME. Infections and anti-tumor necrosis factor alpha therapy. Arthritis Rheum. 2003;48(11):3013-3022.

4. Smitten AL, Simon TA, Hochberg MC, Suissa S. A meta-analysis of the incidence of malignancy in adult patients with rheumatoid arthritis. Arthritis Res Ther. 2008;10(2):R45.

5. Tracey D, Klareskog L, Sasso EH, Salfeld JG, Tak PP. Tumor necrosis factor antagonist mechanisms of action: a comprehensive review. Pharmacol Ther. 2008;117(2):244-279.

6. World Health Organization. Global Tuberculosis Report. World Health Organization; 2014. Available from: http://apps.who.int/iris/bitstr eam/10665/137094/1/9789241564809_eng.pdf. Accessed August 3, 2016.

7. Murray CJL, Ortblad KF, Guinovart C, et al. Global, regional, and national incidence and mortality for HIV, tuberculosis, and malaria during 1990-2013: a systematic analysis for the Global Burden of Disease Study 2013. Lancet. 2014;384(9947):1005-1070.
8. Badawi A, Sayegh S, Sallam M, et al. The global relationship between the prevalence of diabetes mellitus and incidence of tuberculosis: 2000-2012. Glob J Health Sci. 2014;7(2):183-191.

9. Udwadia ZF, Mehra C. Tuberculosis in India. BMJ. 2015;350:H1080.

10. Keane J, Gershon S, Wise RP, et al. Tuberculosis associated with infliximab, a tumor necrosis factor alpha-neutralizing agent. $N$ Engl J Med. 2001;345(15):1098-1104.

11. Nacci F, Matucci-Cerinic M. Tuberculosis and other infections in the anti-tumour necrosis factor-alpha (anti-TNF-alpha) era. Best Pract Res Clin Rheumatol. 2011;25(3):375-388.

12. Byun JM, Lee CK, Rhee SY, et al. Risks for opportunistic tuberculosis infection in a cohort of 873 patients with inflammatory bowel disease receiving a tumor necrosis factor- $\alpha$ inhibitor. Scand J Gastroenterol. 2015;50(3):312-320.

13. Yoo IK, Choung RS, Hyun JJ, et al. Incidences of serious infections and tuberculosis among patients receiving anti-tumor necrosis factor-alpha therapy. Yonsei Med J. 2014;55(2):442-448.

14. Tubach F, Salmon D, Ravaud P, et al. Risk of tuberculosis is higher with anti-tumor necrosis factor monoclonal antibody therapy than with soluble tumor necrosis factor receptor therapy: the three-year prospective French Research Axed on Tolerance of Biotherapies registry. Arthritis Rheum. 2009;60(7):1884-1894.

15. Hammoudeh M, Alarfaj A, Chen DY, Djoudi H, Youseif E, Zhu J. Safety of tumor necrosis factor inhibitors use for rheumatoid arthritis and ankylosing spondylitis in Africa, the Middle East, and Asia: focus on severe infections and tuberculosis. Clin Rheumatol. 2013;32(3): 293-300.

16. Ke WM, Chen LS, Parng IM, Chen WW, On AW. Risk of tuberculosis in rheumatoid arthritis patients on tumour necrosis factor-alpha inhibitor treatment in Taiwan. Int J Tuberc Lung Dis. 2013;17(12): 1590-1595.

17. Mok CC, Chan KY, Lee KL, Tam LS, Lee KW; The Hong Kong Society of Rheumatology. . Factors associated with withdrawal of the anti-TNF $\alpha$ biologics in the treatment of rheumatic diseases: data from the Hong Kong Biologics Registry. Int J Rheum Dis. 2014;17(s3):1-8.

18. Kim EM, Uhm WS, Bae SC, Yoo DH, Kim TH. Incidence of tuberculosis among Korean patients with ankylosing spondylitis who are taking tumor necrosis factor blockers. J Rheumatol. 2011;38(10):2218-2223.

19. Kwon M, Sung M, Kwon Y-J, et al. Active tuberculosis risk with tumor necrosis factor inhibitors after treating latent tuberculosis. J Clin Rheumatol. 2014;20(2):68-73.

20. Navarra SV, Tang B, Lu L, et al. Risk of tuberculosis with anti-tumor necrosis factor- $\alpha$ therapy: substantially higher number of patients at risk in Asia. Int J Rheum Dis. 2014;17(3):291-298.

21. To KW, Reino JJG, Yoo DH, Tam LS. Tumour necrosis factor antagonist and tuberculosis in patients with rheumatoid arthritis: an Asian perspective. Respirology. 2013;18(5):765-773.

22. Chen DY, Shen GH, Chen YM, Chen HH, Hsieh CW, Lan JL. Biphasic emergence of active tuberculosis in rheumatoid arthritis patients receiving TNFalpha inhibitors: the utility of IFNgamma assay. Ann Rheum Dis. 2012;71(2):231-237.

23. Gardam MA, Keystone EC, Menzies R, et al. Anti-tumour necrosis factor agents and tuberculosis risk: mechanisms of action and clinical management. Lancet Infect Dis. 2003;3(3):148-155.

24. Fabroni C, Gori A, Prignano F, Lotti T. A severe complication of antiTNF alfa treatment. G Ital Dermatol Venereol. 2010;145(6):775-777.

25. Cagatay T, Aydin M, Sunmez S, et al. Follow-up results of 702 patients receiving tumor necrosis factor-alpha antagonists and evaluation of risk of tuberculosis. Rheumatol Int. 2010;30(11):1459-1463.

26. He D, Bai F, Zhang S, et al. High incidence of tuberculosis infection in rheumatic diseases and impact for chemoprophylactic prevention of tuberculosis activation during biologics therapy. Clin Vaccine Immunol. 2013;20(6):842-847.

27. Kurt OK, Kurt B, Talay F, et al. Intermediate to long-term followup results of INH chemoprophylaxis prior to anti-TNF-alpha therapy in a high-risk area for tuberculosis. Wien Klin Wochenschr. 2013;125(19-20):616-620. 
28. Sanchez-Moya AI, Dauden E. Incidence of tuberculosis infection in psoriatic patients on anti-TNF therapy: report of a case series with 144 patients. J Eur Acad Dermatol Venereol. 2011;25(6):730-733.

29. Tomšič M, Rotar Ž. The frequency of tuberculosis chemoprophylaxis prior to TNF- $\alpha$ inhibitor treatment, and the incidence tuberculosis infection using a two-step screening algorithm for latent tuberculosis infection: data from the BioRx.si registry. Ann Rheum Dis. 2012;71(11):1909-1911.

30. Gómez-Reino JJ, Carmona L, Valverde VR, Mola EM, Montero MD. Treatment of rheumatoid arthritis with tumor necrosis factor inhibitors may predispose to significant increase in tuberculosis risk: a multicenter active-surveillance report. Arthritis Rheum. 2003;48(8):2122-2127.

31. Lalvani A, Millington KA. Screening for tuberculosis infection prior to initiation of anti-TNF therapy. Autoimmun Rev. 2008;8(2):147-152.

32. Forget EJ, Menzies D. Adverse reactions to first-line antituberculosis drugs. Expert Opin Drug Saf. 2006;5(2):231-249.

33. Nienhaus A, Ringshausen FC, Costa JT, Schablon A, Tripodi D. IFN-gamma release assay versus tuberculin skin test for monitoring TB infection in healthcare workers. Expert Rev Anti Infect Ther. 2013;11(1):37-48.

34. Chen DY, Shen GH, Hsieh TY, Hsieh CW, Lan JL. Effectiveness of the combination of a whole-blood interferon-gamma assay and the tuberculin skin test in detecting latent tuberculosis infection in rheumatoid arthritis patients receiving adalimumab therapy. Arthritis Rheum. 2008;59(6):800-806.

35. Chiu HY, Hsueh PR, Tsai TF. Clinical experience of QuantiFERON® -TB gold testing in patients with psoriasis treated with tumour necrosis factor blockers in Taiwan. Br J Dermatol. 2011;164(3):553-559.

36. Karataş Toğral A, Muştu Koryürek Ö, Şahin M, Bulut C, Yağci S, Ekşioğlu HM. Association of clinical properties and compatibility of the QuantiFERON-TB Gold In-Tube test with the tuberculin skin test in patients with psoriasis. Int J Dermatol. 2015;55(6):629-633.

37. Singanayagam A, Manalan K, Sridhar S, et al. Evaluation of screening methods for identification of patients with chronic rheumatological disease requiring tuberculosis chemoprophylaxis prior to commencement of TNF- $\alpha$ antagonist therapy. Thorax. 2013;68(10):955-961.

38. Martyn-Simmons CL, Mee JB, Kirkham BW, Groves RW, Milburn HJ. Evaluating the use of the interferon- $\gamma$ response to Mycobacterium tuberculosis-specific antigens in patients with psoriasis prior to antitumour necrosis factor- $\alpha$ therapy: a prospective head-to-head cross-sectional study. Br J Dermatol. 2013;168(5):1012-1018.

39. Askling J, Fored CM, Brandt L, et al. Risk and case characteristics of tuberculosis in rheumatoid arthritis associated with tumor necrosis factor antagonists in Sweden. Arthritis Rheum. 2005;52(7):1986-1992.

40. Dixon WG, Hyrich KL, Watson KD, et al. Drug-specific risk of tuberculosis in patients with rheumatoid arthritis treated with anti-TNF therapy: results from the British Society for Rheumatology Biologics Register (BSRBR). Ann Rheum Dis. 2010;69(3):522-528.

41. Emer JJ, Frankel A, Zeichner JA. A practical approach to monitoring patients on biological agents for the treatment of psoriasis. J Clin Aesthet Dermatol. 2010;3(8):20-26.

42. Cagatay T, Kilicaslan Z, Cagatay P, et al. TNF-alpha antagonist therapy modify the tuberculin skin test response. Rheumatol Int. 2011;31(9): $1147-1151$

43. O'Shea MK, Fletcher TE, Beeching NJ, et al. Tuberculin skin testing and treatment modulates interferon-gamma release assay results for latent tuberculosis in migrants. PLoS One. 2014;9(5):e97366.

44. Mohd Hanafiah K, Groeger J, Flaxman AD, Wiersma ST. Global epidemiology of hepatitis $\mathrm{C}$ virus infection: new estimates of age-specific antibody to HCV seroprevalence. Hepatology. 2013;57(4):1333-1342.

45. Díez-Padrisa N, Castellanos LG; PAHO Viral Hepatitis Working Group. Viral hepatitis in Latin America and the Caribbean: a public health challenge. Rev Panam Salud Publica. 2013;34(4):275-281.

46. Szabo SM, Bibby M, Yuan Y, et al. The epidemiologic burden of hepatitis $\mathrm{C}$ virus infection in Latin America. Ann Hepatol. 2012;11(5):623-635.

47. Diehl AM. Cytokine regulation of liver injury and repair. Immunol Rev. 2000;174:160-171.
48. Elsammak M, Refai W, Elsawaf A, Abdel-Fattah I, Abd Elatti E, Ghazal A. Elevated serum tumor necrosis factor alpha and ferritin may contribute to the insulin resistance found in HCV positive Egyptian patients. Curr Med Res Opin. 2005;21(4):527-533.

49. Gutierrez-Reyes G, Lopez-Ortal P, Sixtos S, et al. Effect of pentoxifylline on levels of pro-inflammatory cytokines during chronic hepatitis C. Scand J Immunol. 2006;63(6):461-467.

50. Kishihara Y, Hayashi J, Yoshimura E, Yamaji K, Nakashima K, Kashiwagi S. IL-1 beta and TNF-alpha produced by peripheral blood mononuclear cells before and during interferon therapy in patients with chronic hepatitis C. Dig Dis Sci. 1996;41(2):315-321.

51. Lecube A, Hernández C, Genescà J, Simó R. Proinflammatory cytokines, insulin resistance, and insulin secretion in chronic hepatitis $\mathrm{C}$ patients. Diabetes Care. 2006;29(5):1096-1101.

52. Mendoza EC, Paglieroni TG, Zeldis JB. Decreased phorbol myristate acetate-induced release of tumor necrosis factor- $\alpha$ and interleukin- $1 \beta$ from peripheral blood monocytes of patients chronically infected with hepatitis C virus. J Infect Dis. 1996;174(4):842-844.

53. Ballanti E, Conigliaro P, Chimenti MS, et al. Use of anti-tumor necrosis factor alpha therapy in patients with concurrent rheumatoid arthritis and hepatitis B or hepatitis C: a retrospective analysis of 32 patients. Drug Dev Res. 2014;75(suppl 1):S42-S45.

54. Costa L, Caso F, Atteno M, et al. Long-term safety of anti-TNF-alpha in PsA patients with concomitant HCV infection: a retrospective observational multicenter study on 15 patients. Clin Rheumatol. 2014;33(2): 273-276.

55. Ferri C, Ferraccioli G, Ferrari D, et al. Safety of anti-tumor necrosis factor-alpha therapy in patients with rheumatoid arthritis and chronic hepatitis C virus infection. J Rheumatol. 2008;35(10):1944-1949.

56. Iannone F, La Montagna G, Bagnato G, Gremese E, Giardina AR, Lapadula G. Safety of etanercept and methotrexate in patients with rheumatoid arthritis and hepatitis $\mathrm{C}$ virus infection: a multicenter randomized clinical trial. J Rheumatol. 2014;41(2):286-292.

57. Peterson JR, Hsu FC, Simkin PA, Wener MH. Effect of tumour necrosis factor alpha antagonists on serum transaminases and viraemia in patients with rheumatoid arthritis and chronic hepatitis $\mathrm{C}$ infection. Ann Rheum Dis. 2003;62(11):1078-1082.

58. Prignano F, Ricceri F, Pescitelli L, Zanieri F, Lotti T. Tumour necrosis factor- $\alpha$ antagonists in patients with concurrent psoriasis and hepatitis B or hepatitis C: a retrospective analysis of 17 patients. Br J Dermatol. 2011;164(3):645-647.

59. Nordgaard-Lassen I, Dahlerup JF, Belard E, et al. Guidelines for screening, prophylaxis and critical information prior to initiating antiTNF-alpha treatment. Dan Med J. 2012;59(7):C4480.

60. Pompili M, Biolato M, Miele L, Grieco A. Tumor necrosis factor-alpha inhibitors and chronic hepatitis $\mathrm{C}$ : a comprehensive literature review. World J Gastroenterol. 2013;19(44):7867-7873.

61. Brunasso AMG, Puntoni M, Gulia A, Massone C. Safety of anti-tumour necrosis factor agents in patients with chronic hepatitis $\mathrm{C}$ infection: a systematic review. Rheumatology. 2011;50(9):1700-1711.

62. Giannitti C, Bellisai F, Ferri C, Galeazzi M. Treatment strategies for a patient with rheumatoid arthritis and hepatitis C. Expert Opin Pharmacother. 2009;10(4):579-587.

63. Murdaca G, Spanò F, Contatore M, Guastalla A, Magnani O, Puppo F. Efficacy and safety of etanercept in chronic immune-mediated disease. Expert Opin Drug Saf. 2014;13(5):649-661.

64. Vigano M, Degasperi E, Aghemo A, Lampertico P, Colombo M. AntiTNF drugs in patients with hepatitis B or C virus infection: safety and clinical management. Expert Opin Biol Ther. 2012;12(2):193-207.

65. Chen YM, Chen HH, Chen YH, et al. A comparison of safety profiles of tumour necrosis factor alpha inhibitors and rituximab therapy in patients with rheumatoid arthritis and chronic hepatitis C. Ann Rheum Dis. 2015;74(3):626-627.

66. Singh JA, Furst DE, Bharat A, et al. 2012 Update of the 2008 American College of Rheumatology recommendations for the use of disease-modifying antirheumatic drugs and biologic agents in the treatment of rheumatoid arthritis. Arthritis Care Res (Hoboken). 2012;64(5):625-639. 
67. World Health Organization [webpage on the Internet]. Hepatitis B Fact Sheet. World Health Organization; 2015. Available from: http://www. who.int/mediacentre/factsheets/fs204/en/. Accessed August 3, 2016.

68. Roman S, Jose-Abrego A, Fierro NA, et al. Hepatitis B virus infection in Latin America: a genomic medicine approach. World J Gastroenterol. 2014;20(23):7181-7196

69. Coppola N, Alessio L, Pisaturo M, et al. Hepatitis B virus infection in immigrant populations. World J Hepatol. 2015;7(30):2955-2961.

70. Guidotti LG, Ishikawa T, Hobbs MV, Matzke B, Schreiber R, Chisari FV. Intracellular inactivation of the hepatitis B virus by cytotoxic $T$ lymphocytes. Immunity. 1996;4(1):25-36.

71. Charpin C, Guis S, Colson P, et al. Safety of TNF-blocking agents in rheumatic patients with serology suggesting past hepatitis B state: results from a cohort of 21 patients. Arthritis Res Ther. 2009;11(6):R179.

72. Vassilopoulos D, Calabrese LH. Management of rheumatic disease with comorbid HBV or HCV infection. Nat Rev Rheumatol. 2012;8(6):348-357.

73. Vento S, Cainelli F, Longhi MS. Reactivation of replication of hepatitis $\mathrm{B}$ and $\mathrm{C}$ viruses after immunosuppressive therapy: an unresolved issue Lancet Oncol. 2002;3(6):333-340.

74. Hoofnagle JH. Reactivation of hepatitis B. Hepatology. 2009; 49(5 suppl):S156-S165.

75. Yeo W, Chan HL. Hepatitis B virus reactivation associated with antineoplastic therapy. J Gastroenterol Hepatol. 2013;28(1):31-37.

76. Chung SJ, Kim JK, Park MC, Park YB, Lee SK. Reactivation of hepatitis B viral infection in inactive $\mathrm{HBsAg}$ carriers following anti-tumor necrosis factor-alpha therapy. J Rheumatol. 2009;36(11):2416-2420.

77. Lan JL, Chen YM, Hsieh TY, et al. Kinetics of viral loads and risk of hepatitis B virus reactivation in hepatitis B core antibody-positive rheumatoid arthritis patients undergoing anti-tumour necrosis factor alpha therapy. Ann Rheum Dis. 2011;70(10):1719-1725.

78. Lee YH, Bae SC, Song GG. Hepatitis B virus (HBV) reactivation in rheumatic patients with hepatitis core antigen (HBV occult carriers) undergoing anti-tumor necrosis factor therapy. Clin Exp Rheumatol. 2013;31(1):118-121.

79. Lee YH, Bae S-C, Song GG. Hepatitis B virus reactivation in HBsAgpositive patients with rheumatic diseases undergoing anti-tumor necrosis factor therapy or DMARDs. Int J Rheum Dis. 2013;16(5):527-531.

80. Pérez-Alvarez R, Díaz-Lagares C, García-Hernández F, et al. Hepatitis $B$ virus (HBV) reactivation in patients receiving tumor necrosis factor (TNF)-targeted therapy: analysis of 257 cases. Medicine (Baltimore). 2011;90(6):359-371.

81. Vassilopoulos D, Apostolopoulou A, Hadziyannis E, et al. Long-term safety of anti-TNF treatment in patients with rheumatic diseases and chronic or resolved hepatitis B virus infection. Ann Rheum Dis. 2010;69(7):1352-1355.
82. Ye H, Zhang XW, Mu R, et al. Anti-TNF therapy in patients with HBV infection--analysis of 87 patients with inflammatory arthritis. Clin Rheumatol. 2014;33(1):119-123.

83. Kalyoncu U, Emmungil H, Onat AM, et al. Current antiviral practice and course of Hepatitis B virus infection in inflammatory arthritis: a multicentric observational study (A + HBV study). Eur J Rheumatol. 2015;2(4):149-154.

84. Zhang X, Zhang F, Wu D, et al. Safety of infliximab therapy in rheumatoid arthritis patients with previous exposure to hepatitis B virus. Int $J$ Rheum Dis. 2013;16(4):408-412.

85. Calabrese LH, Zein N, Vassilopoulos D. Safety of antitumour necrosis factor (anti-TNF) therapy in patients with chronic viral infections: hepatitis C, hepatitis B, and HIV infection. Ann Rheum Dis. 2004;63(suppl 2): ii18-ii24.

86. Hwang JP, Lok ASF. Management of patients with hepatitis B who require immunosuppressive therapy. Nat Rev Gastroenterol Hepatol. 2014;11(4):209-219.

87. Mastroianni CM, Lichtner M, Citton R, et al. Current trends in management of hepatitis B virus reactivation in the biologic therapy era. World J Gastroenterol. 2011;17(34):3881-3887.

88. Nard FD, Todoerti M, Grosso V, et al. Risk of hepatitis B virus reactivation in rheumatoid arthritis patients undergoing biologic treatment: extending perspective from old to newer drugs. World $J$ Hepatol. 2015;7(3):344-361.

89. Karadağ Ö, Kaşifoğlu T, Özer B, et al. Viral hepatitis screening guideline before biological drug use in rheumatic patients. Eur J Rheumatol. 2016;3(1):25-28.

90. Ai JW, Zhang S, Ruan QL, et al. The risk of tuberculosis in patients with rheumatoid arthritis treated with tumor necrosis factor-alpha antagonist: a metaanalysis of both randomized controlled trials and registry/cohort studies. J Rheumatol. 2015;42(12):2229-2237.

91. Calabrese LH, Cacoub PP. For patients with rheumatic disease and hepatitis C infection: the end of interferon. RMD Open. 2015;1(1):e000008.

92. Iannone F, Cantini F, Lapadula G. Diagnosis of latent tuberculosis and prevention of reactivation in rheumatic patients receiving biologic therapy: international recommendations. J Rheumatol Suppl. 2014;91:41-46.

93. Lok AS, McMahon BJ. Chronic hepatitis B. Hepatology. 2007;45(2): 507-539.

94. Terrault NA, Bzowej NH, Chang KM, Hwang JP, Jonas MM, Murad MH. AASLD guidelines for treatment of chronic hepatitis B. Hepatology. 2016;63(1):261-283.

95. Valls V, Ena J. Short-course treatment of latent tuberculosis infection in patients with rheumatic conditions proposed for anti-TNF therapy. Clin Rheumatol. 2015;34(1):29-34.
Biologics: Targets and Therapy

\section{Publish your work in this journal}

Biologics: Targets and Therapy is an international, peer-reviewed journa focusing on the patho-physiological rationale for and clinical application of Biologic agents in the management of autoimmune diseases, cancers or other pathologies where a molecular target can be identified. This journal is indexed on PubMed Central, EMBase, and Scopus.

\section{Dovepress}

The manuscript management system is completely online and includes a very quick and fair peer-review system, which is all easy to use. Visit http://www.dovepress.com/testimonials.php to read real quotes from published authors. 